\title{
Mobile Phones: Vital Addiction or Lethal Addiction? Mobile Phone Usage Patterns and Assessment of Mobile Addiction among Undergraduate Medical Students in Telangana, India
}

\author{
Vinay Jahagirdar $\mathbb{D}^{1},{ }^{1}$ Kaanthi Rama $\mathbb{D}^{2},{ }^{2}$ Pranavi Soppari $\mathbb{D}^{2},{ }^{2}$ and M. Vijay Kumar $\mathbb{D}^{2}$ \\ ${ }^{1}$ Department of Internal Medicine, University of Missouri Kansas City School of Medicine, Kansas City, MO, USA \\ ${ }^{2}$ Department of Community Medicine, Gandhi Medical College, Secunderabad, India \\ Correspondence should be addressed to Kaanthi Rama; apoorva.rama@gmail.com
}

Received 17 June 2021; Accepted 5 October 2021; Published 20 October 2021

Academic Editor: Elisardo Becona

Copyright (c) 2021 Vinay Jahagirdar et al. This is an open access article distributed under the Creative Commons Attribution License, which permits unrestricted use, distribution, and reproduction in any medium, provided the original work is properly cited.

\begin{abstract}
Background. Increased mobile phone usage among undergraduate medical students causes a detrimental effect on their health. The main focus of this study is to determine the pattern of mobile phone usage among undergraduate medical students in Hyderabad, India, and the detrimental effect on their health due to excess mobile use. Materials and Methods. A cross-sectional study was conducted among undergraduate medical students from various medical colleges in Hyderabad, India, from September 2020 to January 2021. Data were collected from 626 respondents using a semistructured, pretested questionnaire. Smartphone Addiction Scale-Short Version (SAS-SV) was used to assess the risk of smartphone addiction. Microsoft Excel and SAS were employed to analyze the data. Associations were examined using Fisher's exact test. Results. 100\% of the respondents were using mobiles, with $83.2 \%$ spending more than 4 hours on them. Only $22 \%$ reported that no mobile use during classes. Half (51.6\%) admitted to keeping their mobiles close by while sleeping. $84.3 \%$ used social networking apps via their mobiles. Common symptoms arising from prolonged mobile usage included eye strain (67.9\%), blurred vision (31.4\%), and numbness or tingling in palms (30.9\%). $52.70 \%$ of the respondents were at high risk of mobile addiction according to SAS-SV. Screen time more than 4 hours was associated with high risk of mobile addiction $(p<0.0001)$. Significant association was found between high risk of mobile addiction and eye strain $(p<0.0001)$, blurry vision $(p=0.0115)$, numbness/tingling in palms $(p<0.0001)$, and heat/tingling in the auditory area $(p<0.0001)$. Conclusion. The study shows the alarming rate of risk of smartphone addiction among medical students. Students can be encouraged to assess their mobile addiction status and become aware of the issue. More research may be performed to develop standardized tools for early identification of mobile addiction and appropriate therapies for its rectification.
\end{abstract}

\section{Introduction}

Mobile phones are electronic devices with a cellular radio system which can be used over a wide area, without a physical connection to a network. They have become ubiquitous in today's day and age, with easy Internet access making life convenient in terms of social networking, banking, shopping, or to seek knowledge. With the advent of several health-promoting apps, including those involving nutrition, fitness, and mindfulness, mobiles are being increasing used to promote a healthy lifestyle. India's mobile phone base is estimated to reach 820 million by 2022 , placing
India in the second position globally, in terms of population using mobile phones, after China [1, 2]. Mobiles are indispensable for medical students to be in touch with their peers and families as their curriculum entails long working hours where they are confined to the hospital. They are also used extensively as a tool for education and note taking, with increasing availability of e-books, medical podcasts, dosage calculators, and online lectures [3].

Symptoms such as headache, impaired concentration, and fatigue stemming from the prolonged mobile use have been documented [4]. Studies have shown that mobile usage can have a negative impact on biological systems, leading to 
increased stress, sleep disturbances, and depression $[5,6]$. The World Health Organization has classified mobile phone addiction as a form of nonsubstance addiction [7]. Excessive use of mobiles is an acquired compulsive behavioural pattern, consuming time and resources. Despite of the awareness of the consequences, there is persistent escalation of this behaviour. New disorders such as nomophobia or "no mobile phone" phobia and ringxiety have emerged from the excessive use of mobiles. Nomophobia is a psychological condition where one has fear of being away from mobile phone connectivity [8]. It may manifest as anxiety, respiratory alterations, trembling, perspiration, agitation, disorientation, and tachycardia [8]. Ringxiety is a "phantom" experience where a person hallucinates that his mobile is ringing or vibrating, without actually receiving any call or message [9]. Authors have also described terms like textiety, textaphrenia, binge texting, and posttraumatic "text" disorder [10].

Prevalence of mobile addiction in Indian youth ranges between $39 \%$ and $44 \%$ [8]. Medical students are vulnerable to burnouts and emotion exhaustion. Coupled with high intensity academics, their stress can lead to mobile phone addiction [11]. Studies have shown that poor sleep quality in medical students is associated with over use of mobile phones, placing them at increased risk of various physical ailments and mental disorders [6]. The primary objective of this study is to determine the pattern of mobile phone usage among undergraduate medical students in Hyderabad, India. The secondary objectives include the assessment of the detrimental effect on health due to excess mobile use.

\section{Materials and Methods}

A cross-sectional, observational study was conducted between September 2020 and January 2021, among undergraduate medical (MBBS) students in Hyderabad, India.

The prevalence of smartphone addiction was expected to be $50 \%$, as per a study conducted by Nikhita et al. [12]. A sample size of 384 was calculated with $95 \%$ confidence interval and a $5 \%$ margin of error. The final sample size was estimated to be 500 after considering nonrespondents.

A pretest was conducted among 20 students who were not included in the final study. Mobile phone usage patterns were evaluated using a self-administered questionnaire. After assessing the content validity, necessary modifications were made to the questionnaire.

The ensuing semistructured, anonymous questionnaire was shared with participants via Google Forms. Students were explained the reasons for conducting the study and informed consent was taken. No personally identifiable information was collected. Undergraduate medical students, $\geq 18$ years of age, who were willing to participate in the survey were included. Those who did not give consent were excluded.

The questionnaire consisted of 38 compulsory questions, including those from the Smartphone Addiction Scale-Short version (SAS-SV) [13]. This scale is a 10-item, self-reported questionnaire, developed by the Korean team of Kwon et al. for assessment of smartphone addiction. It includes questions on mobile overuse, effect of mobile usage on concentration, health, relationships, and daily life. The effect of mobiles on these parameters were rated by the participants on the 6-point Likert scale, with options ranging from "strongly disagree" (1 point) to "strongly agree" (6 points). A score above 34 points indicates high risk of mobile addiction.

The questionnaire covered demographic details including age, sex, and year of the study in medical school. Psychographic variables included were attitude towards mobile usage and awareness regarding mobile dependence and associated anxiety. Questions related to the effect of mobiles on health, sleep, and physical fitness and the impact of the COVID-19 pandemic on the mobile use were put forward. At the end of the questionnaire, health education was imparted regarding the ill effects of mobile overuse and the ways to limit addicting behaviour.

Though expected sample size was 500, 626 responses were received. All responses were included. They were analyzed and computed on Microsoft Excel and SAS (university edition) to arrive at the results. Associations were evaluated using Fisher's exact test, with $p$ value $<0.05$ taken as significant.

\section{Results}

The total number of respondents was 626. Mean age of the respondents was $20.14 \pm 1.31$ years, with majority of them $(69.30 \%, n=434)$ being females. All the respondents reported mobile usage $(100 \%)$, with the mean age of getting their first mobile being $16.85 \pm 1.94$ years. $70 \%(n=440)$ were using both mobile data and $\mathrm{Wi}-\mathrm{Fi}$ to access Internet. Majority $(83 \%, n=521)$ were using their mobiles for more than 4 hours a day (Figure 1). Most of them $(65 \%, n=406)$ were not using a screen time monitoring app to measure usage. Almost $70 \%$ of the respondents $(n=432)$ were unaware of the terms nomophobia, ringxiety, and textiety (Figure 2). Close to $2 / 3^{\text {rd }}$ of the respondents $(63.10 \%$, $n=396)$ were using headphones, although only $11 \%(n=68)$ were aware that headphone usage can reduce radiation exposure.

$42 \%(n=260)$ admitted to use mobiles during class for texting. Only 22\% $(n=140)$ denied any mobile use during classes. Major mobile applications being used by students included those for social networking (84\%), YouTube (74\%), OTT streaming platforms $(60 \%)$, and for online classes $(48 \%) .90 \%(n=565)$ reported an increase in screen time, since the onset of COVID-19 pandemic.

Kwon et al. suggested that males scoring above 31 and females scoring above 33 are at high risk of mobile addiction [13]. Females were given a higher cutoff since they were found to be more aware of their addiction and had higher self-reporting [13]. According to the suggested cutoffs by Kwon et al., 59.4\% of the respondents were at "high risk" of mobile addiction (Table 1 ). Screen time of $\geq 4$ hours per day was significantly associated with high risk of mobile addiction $(p<0.0001)$.

Responses to questions from the SAS-SV were noted (Table 2). 


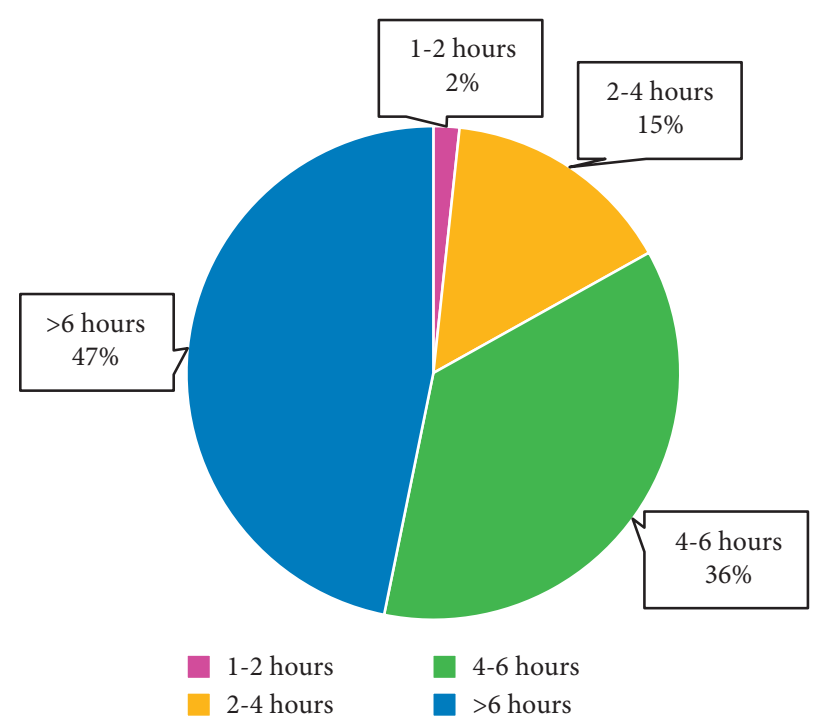

FIGURE 1: Mobile screen time among the respondents.

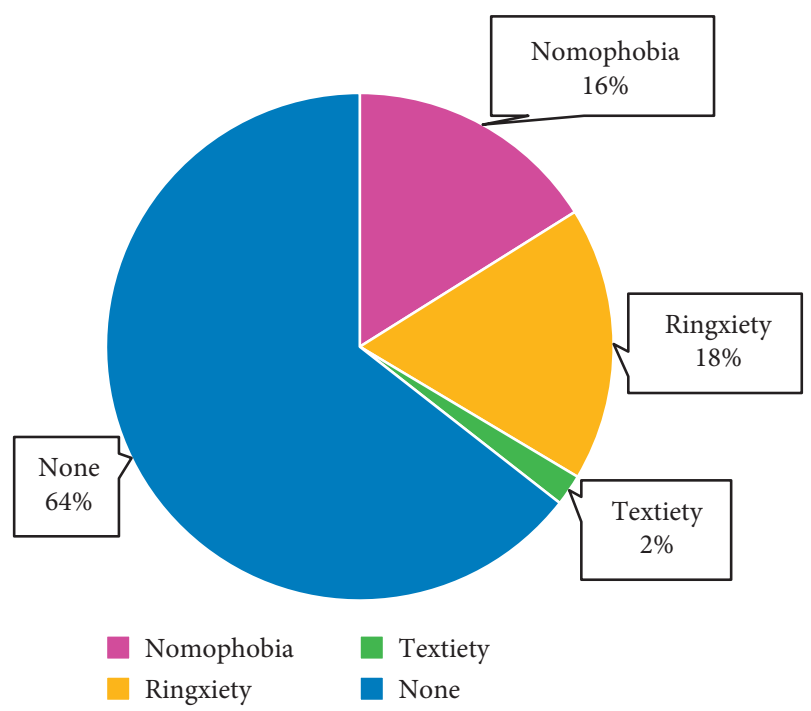

Figure 2: Awareness of terms related to mobile addiction.

TABLE 1: Respondents with high risk of mobile addiction.

\begin{tabular}{lc}
\hline Gender (cutoff) & $N(\%)$ \\
\hline Male $(\geq 31)$ & $123(64.10 \%)$ \\
Female $(\geq 33)$ & $249(57.40 \%)$ \\
Total & $372(59.42 \%)$
\end{tabular}

Close to $80 \%$ of the respondents $(n=497)$ did not switch off their mobile before sleeping, with most of the respondents $(52 \%, n=322)$ keeping it close by. A quarter $(25 \%$, $n=158$ ) reported using their mobiles for an hour before sleeping. More than half $(54 \%, n=337)$ felt that their sleep cycle was affected due to mobile use.

$4 \%(n=26)$ admitted to using their mobiles while driving.

$42 \%(n=265)$ felt that mobile use restricted their day to day physical activities. Half $(51.3 \%, n=321)$ used physical fitness applications on their mobiles. 1 of 4 respondents avoided exercise to due increased mobile use $(26 \%, n=166)$
Half of the respondents $(51 \% n=317)$ were aware that electromagnetic radiation from mobiles can cause health problems. 92\% $(n=574)$ and 25\% $(n=154)$ were aware that mobile usage can cause the detrimental effect on vision and diminished hearing, respectively. Side effects of prolonged mobile usage reported included eye strain $(68 \%)$, heat/tingling in the auditory area (65\%), blurred vision (31\%), and numbness/tingling in palms (31\%). Significant association was found between high risk of mobile addiction and eye strain $(p<0.0001)$, blurry vision $(p=0.0115)$, numbness/ tingling in palms $(p<0.0001)$, and heat/tingling in the auditory area $(p<0.0001)$ (Table 3$)$.

\section{Discussion}

India has the fastest growing mobile user base in the world with 90 mobile connections per 100 of the population [14]. All the respondents in our study owned mobiles (100\%), which is in concordance to other studies conducted among Indian medical students [15]. 59.4\% were at high risk of mobile addiction according to the SAS-SV scale. This is similar to the burden estimated by other studies that utilized the SAS-SV scale-Dharmadikari et al. who found $46.15 \%$ addiction among 195 medical students in Maharashtra and Kumar et al. who found $44.7 \%$ addiction among 150 medical students pursuing internship in a tertiary care hospital in South India $[16,17]$. However, it is higher than the $39-44 \%$ smartphone addiction rate reported in the general Indian population, in the meta-analysis and systemic review done by Davey and Davey [18]. This may be attributed to the long working hours medical students spend away from their families and friends, which make them more dependent on their mobiles.

81.1\% reported more than 4 hours/day of screen time. This is substantially higher than the $60 \%$ reported by Ammati et al. and the $46 \%$ reported by Dasgupta et al. in 2017, among medical students from West Bengal $[15,19]$. The ongoing COVID-19 pandemic, which has shifted teaching from lecture 
TABLE 2: Responses to questions from the SAS-SV.

\begin{tabular}{|c|c|c|c|c|c|c|}
\hline & $\begin{array}{c}\text { Strongly } \\
\text { disagree, } N \\
(\%) \\
\end{array}$ & $\begin{array}{l}\text { Disagree, } N \\
(\%)\end{array}$ & $\begin{array}{c}\text { Weakly } \\
\text { disagree, } N \\
(\%)\end{array}$ & $\begin{array}{c}\text { Weakly } \\
\text { agree, } N(\%)\end{array}$ & $\begin{array}{l}\text { Agree, } N \\
(\%)\end{array}$ & $\begin{array}{c}\text { Strongly } \\
\text { agree, } N(\%)\end{array}$ \\
\hline Missing planned work due to smartphone use & $66(10.5 \%)$ & $98(15.7 \%)$ & $49(7.8 \%)$ & $136(21.7 \%)$ & $\begin{array}{c}183 \\
(29.2 \%)\end{array}$ & $94(15 \%)$ \\
\hline $\begin{array}{l}\text { Having a hard time concentrating in class, while } \\
\text { doing assignments, or while working due to } \\
\text { smartphone use }\end{array}$ & $46(7.3 \%)$ & $118(18.8 \%)$ & $51(8.1 \%)$ & $137(21.9 \%)$ & $\begin{array}{c}172 \\
(27.5 \%)\end{array}$ & $102(16.3 \%)$ \\
\hline $\begin{array}{l}\text { Feeling pain in the wrists or at the back of the neck } \\
\text { while using a smartphone }\end{array}$ & $76(12.1 \%)$ & $133(21.2 \%)$ & $43(6.9 \%)$ & $149(23.8 \%)$ & $\begin{array}{c}157 \\
(25.1 \%)\end{array}$ & $68(10.9 \%)$ \\
\hline $\begin{array}{l}\text { Would not be able to stand not having a } \\
\text { smartphone }\end{array}$ & $93(14.9 \%)$ & $155(24.8 \%)$ & $74(11.8 \%)$ & $105(16.8 \%)$ & $\begin{array}{c}139 \\
(22.2 \%)\end{array}$ & $60(9.6 \%)$ \\
\hline $\begin{array}{l}\text { Feeling impatient and fretful when I am not } \\
\text { holding my smartphone }\end{array}$ & $132(21.1 \%)$ & $193(30.8 \%)$ & $87(13.9 \%)$ & $112(17.9 \%)$ & $\begin{array}{c}68 \\
(10.9 \%)\end{array}$ & $34(5.4 \%)$ \\
\hline $\begin{array}{l}\text { Having my smartphone in my mind even when I } \\
\text { am not using it }\end{array}$ & $139(22.2 \%)$ & $219(35 \%)$ & $65(10.4 \%)$ & $89(14.2 \%)$ & $\begin{array}{c}79 \\
(12.6 \%)\end{array}$ & $35(5.6 \%)$ \\
\hline $\begin{array}{l}\text { I will never give up using my smartphone even } \\
\text { when my daily life is already greatly affected by it }\end{array}$ & $164(26.2 \%)$ & $211(33.7 \%)$ & $84(13.4 \%)$ & $90(14.4 \%)$ & $57(9.1 \%)$ & $20(3.2 \%)$ \\
\hline $\begin{array}{l}\text { Constantly checking my smartphone so as not to } \\
\text { miss conversations between other people on } \\
\text { Twitter or Facebook }\end{array}$ & $162(25.9 \%)$ & $178(28.4 \%)$ & $53(8.5 \%)$ & $104(16.6 \%)$ & $\begin{array}{c}101 \\
(16.1 \%)\end{array}$ & $28(4.5 \%)$ \\
\hline Using my smartphone longer than I had intended & $22(3.5 \%)$ & $60(9.6 \%)$ & $28(4.5 \%)$ & $111(17.7 \%)$ & $\begin{array}{c}249 \\
(39.8 \%)\end{array}$ & $156(24.9 \%)$ \\
\hline $\begin{array}{l}\text { The people around me tell me that I use my } \\
\text { smartphone too much }\end{array}$ & $49(7.8 \%)$ & $126(20.1 \%)$ & $57(9.1 \%)$ & $128(20.4 \%)$ & $\begin{array}{c}185 \\
(29.6 \%)\end{array}$ & $81(12.9 \%)$ \\
\hline
\end{tabular}

halls to online virtual classrooms, may be the cause for this discordance. Longer mobile screen time was significantly associated with increased mobile phone addiction $(p<0.0001)$. This is in concordance to the study published by Pavithra et al. among 200 medical students from Bangalore [20].

Mobile data were used to access the Internet by $93.80 \%$, similar to the $87 \%$ reported by Basu et al. among 388 medical students from New Delhi in 2017 [21]. Cheaper access to mobile data has exponentially increased mobile data consumption in India [22].

Social media applications (84.4\%) were more widely used than gaming apps (31.2\%). This is similar to the results published by Tang et al. in 2017 who compared mobile addiction patterns amongst 3267 undergraduate students of various fields from the United States, China, and Singapore, which found that Asian students were using their mobiles more for networking, compared to their American counterparts, who used it more for gaming [23]. Ammati et al. also found that $46 \%$ students utilized their mobiles for social networking, compared to $7.9 \%$ who used it for gaming [15].

Only $22.40 \%$ reported that they did not use mobile phones during class hours. This is similar to the $15 \%$ reported by Siddiqi et al. in their study conducted among 129 medical students from Oman [24]. More than $3 / 4^{\text {th }}$ of the students use their mobiles during class hours, mainly for text messaging (41.50\%). World-over, medical students are being encouraged to utilize electronic devices for educative purposes. However, misuse of these devices has become rampant. Students can be asked to switch off mobile phones during classes to minimize distractions.

Headphone usage was reported by $63.10 \%$, a little lower than the $83 \%$ reported by Siddiqi et al. [24]. $43.7 \%$ were unaware of that headphone usage can help mitigate radiation risk from mobiles, whereas $90 \%$ of the Omanian students were aware of it [24]. More awareness needs to be spread regarding the use of hands-free devices or the speaker option, instead of keeping the mobile close to the ear. This may reduce the health risk caused by radio frequency radiations of mobile phones [25].

$80 \%$ did not switch off their mobiles before going to bed, with $92 \%$ keeping them within 5 feet. This is similar to the results published by Siddiqi et al. where $70 \%$ left their mobiles on during bedtime [24]. More than half of our respondents $(53.80 \%)$ felt that their sleep quality was affected due to mobiles. Studies have shown that increased mobile use is associated with reduced melatonin production and poor sleep quality $[26,27]$. It is safer to turn off mobile data/Wi-Fi before sleeping and keep the mobile as far as possible. Shifting to a conventional bell alarm can help in keeping the mobile away.

$65.7 \%$ agreed to have difficulty in concentration while working due to mobile use. This is substantially higher than the $26.4 \%$ reported by Basu et al. in 2018 among 388 medical students from New Delhi [21]. 62.9\% of our respondents agreed that their friends and family complained that they use their mobile too much. This is way higher than the $20 \%$ reported by Aggarwal et al. in 2012 among 192 postgraduate medical students of a tertiary care institute in North India [28]. This shows that there is an increasing burden of the problems caused by mobile addiction over the years.

$53 \%$ of our respondents believed that the mobile is a necessary tool to stay connected with their families, whereas $83 \%$ reported the same in a study conducted by Dixit et al. [29]. 
TABle 3: Comparison of mobile usage patterns and symptoms arising from prolonged mobile usage patterns among those with high risk and those not at high risk of mobile addiction.

\begin{tabular}{|c|c|c|c|}
\hline \multicolumn{4}{|c|}{ High risk of mobile addiction } \\
\hline Variables & $\begin{array}{c}\text { Present }(n=372), N \\
(\%)\end{array}$ & $\begin{array}{c}\text { Absent }(n=352), N \\
(\%)\end{array}$ & $P$ value $^{\#}$ \\
\hline $\begin{array}{l}\text { Gender } \\
\text { Male } \\
\text { Female } \\
\end{array}$ & $\begin{array}{l}123(19.6 \%) \\
249(39.8 \%) \\
\end{array}$ & $\begin{array}{c}69(11 \%) \\
185(29.5 \%) \\
\end{array}$ & 0.1335 \\
\hline $\begin{array}{c}\text { Screen time } \\
<4 \text { hours } \\
\geq 4 \text { hours } \\
\end{array}$ & $\begin{array}{c}33(5.3 \%) \\
339(54.1 \%) \\
\end{array}$ & $\begin{array}{c}73(11.7 \%) \\
181(28.9 \%) \\
\end{array}$ & $<0.0001$ \\
\hline $\begin{array}{l}\text { Age } \\
\quad \leq 20 \\
\text { years } \\
>20 \\
\text { years }\end{array}$ & $\begin{array}{l}251(20.1 \%) \\
121(19.3 \%)\end{array}$ & $\begin{array}{l}153(24.4 \%) \\
101(26.1 \%)\end{array}$ & 0.07 \\
\hline $\begin{array}{l}\text { Age of first } \mathrm{r} \\
\leq 20 \\
\text { years } \\
>20 \\
\text { years } \\
\end{array}$ & $\begin{array}{l}\text { mobile } \\
\qquad 123(19.6 \%) \\
249(39.8 \%)\end{array}$ & $\begin{array}{l}65(10.4 \%) \\
189(30.2 \%)\end{array}$ & 0.0508 \\
\hline $\begin{array}{l}\text { Blurry vision } \\
\text { Maybe } \\
\text { Yes } \\
\text { No } \\
\end{array}$ & $\begin{array}{c}39(6.2 \%) \\
129(20.6 \%) \\
204(32.6 \%) \\
\end{array}$ & $\begin{array}{c}19(3 \%) \\
67(10.7 \%) \\
168(26.9 \%) \\
\end{array}$ & 0.0115 \\
\hline $\begin{array}{l}\text { Eye strain } \\
\text { Maybe } \\
\text { Yes } \\
\text { No }\end{array}$ & $\begin{aligned} & 45(7.2 \%) \\
& 281(44.9 \%) \\
& 46(7.3 \%) \\
&\end{aligned}$ & $\begin{array}{c}35(5.6 \%) \\
143(22.8 \%) \\
76(12.1 \%) \\
\end{array}$ & $<0.0001$ \\
\hline $\begin{array}{l}\text { Numbness/ti } \\
\text { Maybe } \\
\text { Yes } \\
\text { No } \\
\end{array}$ & $\begin{array}{c}\text { ingling in palms } \\
45(7.2 \%) \\
135(21.6 \%) \\
192(30.7 \%)\end{array}$ & $\begin{array}{c}17(2.8 \%) \\
58(9.3 \%) \\
179(28.6 \%) \\
\end{array}$ & $<0.0001$ \\
\hline $\begin{array}{l}\text { Heat/tingling } \\
\text { Maybe } \\
\text { Yes } \\
\text { No } \\
\end{array}$ & $\begin{array}{c}\text { in the auditory area } \\
42(6.7 \%) \\
117(18.7 \%) \\
213(34 \%)\end{array}$ & $\begin{array}{c}23(3.7 \%) \\
38(6 \%) \\
193(31 \%) \\
\end{array}$ & $<0.0001$ \\
\hline
\end{tabular}

${ }^{\#}$ Fishers exact test.

The strength of the present study is that its sample provides a good representation of medical students. It focusses on students, amongst whom mobile addiction is rampant. The main limitation of the study is that since it includes a relatively young and highly educated group, it cannot be generalized.

\section{Conclusion}

Mobile addiction has become a public health issue worldover. It has gained more limelight in developing countries like India, which have a younger population. The present study only shows the alarming increase in prevalence of smartphone addiction among young medical students. There is a pressing need for research into mobile phone usage patterns amongst medical students and doctors and the ill effects of the same. Students can be encouraged to assess their risk of mobile addiction status via online tools and become aware of this issue. Mobile addiction, like any other behavioural addiction, could be included in the Diagnostic and Statistical Manual of Mental Disorders (DSMV). More research studies can be done into standardized tools for early identification and appropriate therapies for rectification of mobile addiction.

\section{Data Availability}

The literature review data used to support the findings of this study are included within the article.

\section{Conflicts of Interest}

The authors declare that they have no conflicts of interest.

\section{References}

[1] economictimes.indiatimes.com, "Indian to have 820 million smartphone users by 2022," 2020, https://economictimes. indiatimes.com/industry/telecom/telecom-news/indian-tohave-820-million-smartphone-users-by-2022/articleshow/ $76876369 . \mathrm{cms}$ ?from $=\mathrm{mdr}$.

[2] statistia.com, "Smart phone user penetration rate as share of mobile phone users India 2014-2020," 2021, https://www. statista.com/statistics/257048/smartphone-user-penetrationin-india/.

[3] M. Latif, I. Hussain, R. Saeed, M. Qureshi, and U. Maqsood, "Use of smart phones and social media in medical education: trends, advantages, challenges and barriers," Acta Informatica Medica, vol. 27, no. 2, pp. 133-138, 2019.

[4] A. Szyjkowska, A. Bortkiewicz, W. Szymczak, and T. Makowiec-Dabrowska, "Subjective symptoms related to mobile phone use--a pilot study," Polski Merkuriusz Lekarski: Organ Polskiego Towarzystwa Lekarskiego, vol. 19, pp. 529532, 2005.

[5] K. K. Kesari, M. H. Siddiqui, R. Meena, H. N. Verma, and S. Kumar, "Cell phone radiation exposure on brain and associated biological systems," Indian Journal of Experimental Biology, vol. 51, pp. 187-200, 2013.

[6] S. Thomée, A. Härenstam, and M. Hagberg, "Mobile phone use and stress, sleep disturbances, and symptoms of depression among young adults-a prospective cohort study," BMC Public Health, vol. 11, no. 1, p. 66, 2011.

[7] who.int. World Health Organisation, "Management of substance abuse," 2021, https://www.who.int/substance_abuse/ terminology/definition1/en/.

[8] S. Bhattacharya, M. Bashar, A. Srivastava, and A. Singh, "NOMOPHOBIA: NO MObile PHone PhoBIA," Journal of Family Medicine and Primary Care, vol. 8, no. 4, pp. 1297-1300, 2019.

[9] D. J. Kruger and J. M. Djerf, "High ringxiety: attachment anxiety predicts experiences of phantom cell phone ringing," Cyberpsychology, Behavior, and Social Networking, vol. 19, no. 1, pp. 56-59, 2016.

[10] R. Nehra, N. Kate, S. Grover, N. Khehra, and D. Basu, "Does the excessive use of mobile phones in young adults reflect an emerging behavioral addiction?" Journal of Postgraduate Medicine Education and Research, vol. 46, pp. 177-182, 2012.

[11] S. Grover, S. Sahoo, A. Bhalla, and A. Avasthi, "Psychological problems and burnout among medical professionals of a tertiary care hospital of North India: a cross-sectional study," Indian Journal of Psychiatry, vol. 60, no. 2, pp. 175-188, 2018. 
[12] C. S. Nikhita, P. R. Jadhav, and S. A. Ajinkya, "Prevalence of mobile phone dependence in secondary school adolescents," Journal of Clinical and Diagnostic Research: Journal of Clinical and Diagnostic Research, vol. 9, no. 11, pp. VC06-VC09, 2015.

[13] M. Kwon, D.-J. Kim, H. Cho, and S. Yang, "The smartphone addiction scale: development and validation of a short version for adolescents," PLoS One, vol. 8, no. 12, p. e83558, 2013.

[14] data.worldbank.org. World Bank, "Mobile cellular subscriptions (per 100 people)-India," 2021, https://data.worldbank. org/indicator/IT.CEL.SETS.P2?locations=IN.

[15] R. Ammati, A. Kakunje, R. Karkal, D. Nafisa, G. Kini, and P. Chandrashekaran, "Smartphone addiction among students of medical university in South India: a cross-sectional study," Annals of International Medical and Dental Research, vol. 4, 2018.

[16] S. P. Dharmadhikari, S. D. Harshe, and P. P. Bhide, "Prevalence and correlates of excessive smartphone use among medical students: a cross-sectional study," Indian Journal of Psychological Medicine, vol. 41, no. 6, pp. 549-555, 2019.

[17] V. A. Kumar, V. Chandrasekaran, and H. Brahadeeswari, "Prevalence of smartphone addiction and its effects on sleep quality: a cross-sectional study among medical students," Industrial Psychiatry Journal, vol. 28, no. 1, pp. 82-85, 2019.

[18] S. Davey and A. Davey, "Assessment of smartphone addiction in Indian adolescents: a mixed method study by systematicreview and meta-analysis approach," International Journal of Preventive Medicine, vol. 5, no. 12, pp. 1500-1511, 2014.

[19] P. Dasgupta, S. Bhattacherjee, S. Dasgupta, J. K. Roy, A. Mukherjee, and R. Biswas, "Nomophobic behaviors among smartphone using medical and engineering students in two colleges of West Bengal," Indian Journal of Public Health, vol. 61, no. 3, pp. 199-204, 2017.

[20] M. B. Pavithra, M. Suwarna, and T. S. Mahadeva Murthy, "A study on nomophobia-mobile phone dependence, among students of a medical college in Bangalore," National Journal of Community Medicine, vol. 6, no. 3, pp. 340-344, 2015.

[21] S. Basu, S. Garg, M. M. Singh, and C. Kohli, "Addiction-like behavior associated with mobile phone usage among medical students in Delhi," Indian Journal of Psychological Medicine, vol. 40, no. 5, pp. 446-451, 2018.

[22] timesofindia.indiatimes.com. Times of India, "Indians gorging on mobile data, usage goes up 15 times in 3 yrs," 2018, https://timesofindia.indiatimes.com/business/india-business/ indians-gorging-on-mobile-data-usage-goes-up-15-times-in3-yrs/articleshow/64432913.cms.

[23] C. S.-K. Tang, Y. W. Koh, and Y. Gan, "Addiction to internet use, online gaming, and online social networking among young adults in China, Singapore, and the United States," Asia-Pacific Journal of Public Health, vol. 29, no. 8, pp. 673-682, 2017.

[24] N. Siddiqi, F. Jahan, F. Moin, F. Al-Shehhi, and F. Al-Balushi, "Excessive use of mobile phones by medical students: should precautions be taken?" Biomedical and Pharmacology Journal, vol. 10, no. 4, pp. 1631-1638, 2017.

[25] A. B. Miller, M. E. Sears, L. L. Morgan et al., "Risks to health and well-being from radio-frequency radiation emitted by cell phones and other wireless devices," Frontiers in Public Health, vol. 7, p. 223, 2019.

[26] A. Mohammadbeigi, R. Absari, F. Valizadeh et al., "Sleep quality in medical students; the impact of over-use of mobile cell-phone and social networks," Journal of Research in Health Sciences, vol. 16, no. 1, pp. 46-50, 2016.
[27] S. Yogesh, S. Abha, and S. Priyanka, "Mobile usage and sleep patterns among medical students," Indian Journal of Physiology and Pharmacology, vol. 58, no. 1, pp. 100-103, 2014.

[28] M. Aggarwal, S. Grover, and S. Debasish, "Mobile phone use by resident doctors: tendency to addiction-like behaviour," German Journal of Psychiatry, vol. 15, pp. 50-55, 2012.

[29] S. Dixit, H. Shukla, A. Bhagwat et al., "A study to evaluate mobile phone dependence among students of a medical college and associated hospital of central India," Indian Journal of Community Medicine, vol. 35, no. 2, pp. 339-341, 2010. 